HOW THE GREEKS BUILT CITIES 


\title{
HOW THE GREEKS BUILT CITIES
}

\author{
B Y \\ R. E. WY CHERLEY
}

Second Edition

MACMILLAN EDUCATION 
ISBN 978-1-349-00338-9 ISBN 978-1-349-00336-5 (eBook)

DOI 10.1007/978-1-349-00336-5

Copyright (c) R. E. Wycherley 1962

First Edition 1949

Second Edition 1962

Softcover reprint of the hardcover 2nd edition 1962 978-0-333-04962-4

MACMILLAN AND COMPANY LIMTTED

St Martin's Street London WC2

also London Bombay Calcutta Madras Melbourne

THE MACMILLAN COMPANY OF CANADA LIMITED

Toronto 


\section{PREFACE TO SECOND EDITION}

7 HE nineteen-fifties have seen a phenomenal renewal of archaeological investigation in Greek lands. The annual Archaeological Reports published by the Hellenic Society and the British School at Athens give a useful conspectus of this work and show its astonishing range and variety. Professor J. M. Cook's report on Greek Archaeology in Western Asia Minor (I960) is especially full of interest for the history of the art which can best be described by the modern Greek word poleodomike.

Much new light has been thrown on the antecedents, origins and prototypes of the Greek city, though this light is often fitful or kaleidoscopic, and for the later periods a mass of new illustrative material has been found. In spite of all this I had no desire to re-write this book completely. Our idea of the classical Hellenic city as a whole and of its principal elements remains essentially the same. When Professor R. Martin's excellent book L'Urbanisme dans la Grèce Antique appeared in 1956, I found myself in heartfelt agreement with almost every word of his Conclusion.

Changes in the main body of the text have been kept to a minimum ; but many new or improved plans, and a few new photographs, have been substituted for the old ones; and an extensive series of supplementary notes draws attention to some of the most helpful recent work, on particular sites and in general studies, and briefly indicates its importance.

The work of revision has benefited greatly from a period spent at the Institute for Advanced Study at Princeton, and from two visits to Greece assisted by generous grants from the American Philosophical Society of 


\section{PREFACE TO SECOND EDITION}

Philadelphia. At Athens Professor H. A. Thompson and his colleagues in the agora have been very helpful as always; Mr. J. Travlos in particular has generously supplied me with material. Mr. Henry Robinson, Director of the American School at Athens, kindly provided me with copies of a series of plans of the agora district of Corinth, by Mr. Travlos; I am asked to say that these plans, on which fig. I4 is based, were not yet in final form. Mr. I. D. Kondis, of the Department of Antiquities at Athens, sent me much useful material on Rhodes and other sites. Mr. J. Ellis Jones of Bangor drew fig. 2 and fig. I4, and made many suggestions.

For permission to use plans, drawings and photographs I am very grateful to the following: the American School of Classical Studies at Athens, and Mr. J. Travlos (I, II, I3, I4, 24, 32, 4I, 48, XVIa); the British School at Athens and the editors of its Annual (8); the German Archaeological Institute, Athens, and Gebr. Mann Verlag, Berlin (29) ; Mr. I. D. Kondis (26, I) ; Mr. G. P. Stevens and the Royal Ontario Museum, Toronto (VIIb).

When this book was first taking shape I received timely encouragement from Mr. Lewis Mumford; in introducing this new edition I should like to quote from his latest work The City in History. 'The recovery of the essential values that first were incorporated in the ancient cities, above all those of Greece, is a primary condition for the further development of the city in our time.'

University College of North Wales

R. E. W.

September 196I 


\section{PREFACE TO FIRST EDITION}

$7{ }^{\text {HE }}$ purpose of this brief survey of Hellenic architecture is to define the form of the ancient Greek

1 city and the place of certain elements in it; and since the place of some of these elements in the whole depends on their own form, I shall add a little about the nature of a number of characteristically Greek buildingtypes, without attempting, however, to cover the whole range. Incidentally, I hope, this treatment will relate architecture more closely to Greek life. All this makes a very ambitious project for a short work, and the result can at best be hardly more than a programme for a series of more thorough and detailed studies. I am conscious of many omissions and much unevenness of treatment, though this is partly due to the difficult conditions of recent years and the inaccessibility of material. There is room for a number of detailed works such as W. A. McDonald's Meeting-Places of the Greeks, on particular types of Greek building, as well as for a new study of Greek town-planning to supplement von Gerkan's indispensable work, and I should be glad to furnish further material to anyone working on any of these lines. But I hope that even the present brief treatment will suggest new ways of looking at Greek architecture and raise again the question whether it has not more than a general historical or aesthetic interest nowadays.

The great glory of Greek architecture is the temple. The Greeks dedicated the finest fruits of their artistic genius, and a large proportion of their limited funds and resources, to the gods. The development of the temple 
and of the Doric and Ionic orders, which find their perfect expression in the temple, quite rightly takes first place in the history of Greek architecture; the harmonies and refinements of the orders have an aesthetic value equal to that of the best sculpture. But although this beauty can still inspire, it is apt to seem a little remote. It may help to bring Greek architecture into closer contact with our own ways of thought if the structure and plan of the city - the treatment of which is apt to be relegated to the last chapter - are dealt with first.

Town-planning and town-building are matters of peculiar interest today; new towns are being designed and great old cities are rising in new forms from their ruins, slowly and with difficulty, as did Athens and Miletus after the Persian Wars. In these circumstances the experience of the Greeks, who were great city-builders, has a renewed interest; and I think it will be found that in some things the principles of modern town-planning are akin to the way of the Greeks. The Greek city, at its best, was a compact community, capable in itself of a very high degree of political and cultural life, not overwhelmingly big, organized by and for a large body of free citizens ; and its outward, architectural form accurately reflected its inner nature. Of course, the conditions and problems of today are very different, though not entirely so, and we shall see obvious contrasts at almost every point. But there is an affinity in general character which goes deeper than particular analogies, just as ancient Greek literature has a new significance which cannot be illustrated by particular quotations from Plato or Thucydides, however 'topical'. It is best to let the facts speak for themselves; but perhaps one might say that the 
essential link lies in this - the architecture of the polis grew out of the needs, ways of life, traditions and ideas of its citizens, and followed these at every point, without pursuing the artificial and the extravagant. Restraint and economy were inevitable.

I shall concentrate on the Hellenic city of the sixth, fifth and fourth centuries, when politically and culturally it was at the highest level of its development ; it will not be necessary to become deeply involved in problems of origins and earlier history, or to cover systematically the succeeding 'Hellenistic' period; but I shall inevitably look both backwards and forwards from this view-point from time to time. Hellenic architecture began in a modest way early in the first millennium B.c., but the traditions of the preceding Minoan age were not entirely lost; and at the other end of the scale, Hippodamian townplanning did not bear its full fruit till Hellenistic times; some typically Hellenic building-types were architecturally immature in the fifth century - indeed only the temple had reached full maturity - and one has to pursue their history for a further couple of centuries to reach a suitable stopping-point. Peculiarly Hellenistic developments, on the other hand, are outside my present scope.

'Hellenic', 'Hellenistic' and such terms are largely conventional, and one's use of them needs definition. The civilization which emerged in Greece in the early centuries of the first millennium B.c. was the result of the superimposition on an older culture (the 'Minoan') of a number of new elements which entered in waves from the north. The name Hellenic is most properly applied, I believe, to the final compound, after the last important ingredient had been added and the whole had become 
comparatively stabilized. At the other end again, after the Macedonian conquest in the latter part of the fourth century, the Greek cities lost something vital, though not without certain gains, and some of the finer qualities of Greek art and architecture evaporated ; and the modified form of Greek culture which is found in the succeeding centuries can be conveniently distinguished as 'Hellenistic', though the lower limit of the age to which the name is applicable is not clear; from the first century B.C. onwards, when Roman power had supplanted that of the Hellenistic monarchs in the eastern Mediterranean, one usually speaks of 'Roman' times in Greece.

Inconsistencies and oddities will be found, I am sure, in my transliteration of Greek names and other Greek words. Unusual strength of mind is required, besides extreme care, if one is to observe strict principles in this matter, and I hardly think I have succeeded.

Full acknowledgment of the source of each plan and photo is made immediately underneath it, the only place where it is sure to be seen. I must thank the Press Board of the University of Wales for a very generous grant towards the cost of assembling materials for the illustrations ; Mr. T. E. Jones and Mr. I. ap Thomas of Bangor for redrawing to my instructions figures $4,25,26,28,34$ and $5 \mathrm{I}$; and many authors and publishers who have given me permission to use material. I have done my best to make contact with all concerned, but in recent conditions this has sometimes been impossible. In such cases I have still included the material, if its omission would have been a serious loss; I should like to thank those concerned and shall be very glad to make further amends if opportunity occurs. In taking this course I 


\section{PREFACE TO FIRST EDITION}

have been reassured by the invariable generosity and courtesy which I have received, now no less than before the war, from scholars and publishers of all countries. In particular, the man to whom the study of this subject owes more than to any other-A. von Gerkan - says, 'Ich bin der Ansicht, dass publiziertes Material für die Wissenschaft frei sein sollte'. Professor Homer A. Thompson very kindly sent me up-to-date information (September 1947) on the agora of Athens, and new plans and photographs of the new model which had not at the time been published. Professor F. Krischen has allowed me to make free use of his excellent reconstructed drawings of Greek cities. Before the war Dr. H. Schleif readily gave me permission to use for other purposes photos of his carefully constructed models; this time my letter was returned marked 'Verstorben'. Thanks are also due to the following: Mr. T. J. Dunbabin (Pl. XVI (b)) ; Dr. E. Fiechter (Pl. XIII (a) and fig. 46) ; Dr. A. von Gerkan (numerous plans from Griechische Städteanlagen and Milet); Mr. D. M. Jones (Pls. XII (b) and XVI (a)) ; Professor D. M. Robinson (plans from Olynthus ; Professor Robinson has also sent me other useful material on Greek houses); Dr. F. Tritsch (fig. Is); the Hellenic Society (Pls. III (a), IX, XI, XIV (b), figs. 24, 30) ; the Royal Institute of British Architects (figs. I6, I7 and 23 were originally drawn at the Institute for an article which appeared in the Journal of the R.I.B.A., I7th October 1938; the Editor has also very kindly let me have the block from which was printed the plan of Olynthus in the Journal of 13th January 1947); the Loeb Classical Library and William Heinemann, Ltd. (figs. I, 24 and 27 ; these plans were originally drawn at the Cambridge Uni- 
versity Press for inclusion in vol. $v$ of the Loeb Pausanias); the Archaeological Institute of America (figs. 49 and 52); the American School of Classical Studies at Athens (fig. 28 and numerous plans from Hesperia; also Pl. IV); the Metropolitan Museum of Art, New York (PI. VII (a)); the German Archaeological Institute (Pls. X and XIII (b)) ; the Clarendon Press, Oxford (figs. 35 and 40); E. de Boccard, Paris (figs. 2, Io and 48); Biederstein Verlag, München (formerly C. H. Beck) (figs. I, 32 and 45); Alfred Druckenmüller Verlag (formerly J. B. Metzler) (fig. 7); Verlag Gebr. Mann, Berlin (drawings from Krischen); W. de Gruyter \& Co., Berlin (Pls. II (b) and XII (a), and plans from von Gerkan) ; Deutscher Kunstverlag and Staatliche Bildstelle (PI. III (b)) ; Kunstgeschichtliches Seminar der Universität Marburg (Lahn) (Pls. I and VIII (a)).

Finally, I should like to thank the following, if I may do so without involving them in any kind of responsibility, for suggestions and encouragement given at various stages of the work : Dr. R. A. Browne, Professor R. A. Cordingley, Mr. J. A. Davison, Dr. A. von Gerkan, Dr. A. W. Pickard-Cambridge, Professor D. S. Robertson, Mr. C. T. Seltman, Dr. F. J. Tritsch, and Professor T. B. L. Webster; I am grateful also to my wife for help with proof-reading and indexing, and to Messrs. Macmillan, and in particular Mr. H. Cowdell, for the care they have taken with the production of this work.

On the occasion of the quincentenary of Queens' College, Cambridge, this book is dedicated to members past and present, and in particular to A. B. Cook.

Universtty College of North Wales

R. E. W.

December 1947 


\section{CONTENTS}

PrEFACE

PAGB

LIST OF ILLUSTRATIONS XV

ABBREviations xviii

INTRODUCTORY Xix

I Growth of the Greek City I

II GREEK TOWN-PLANNING Is

III FORTIFICATIONS 36

IV THE AgOrA 50

V Shrines and Official Buildings 87

VI Gymnasium, Stadium and Theatre 139

VII Greex Houses 175

VIII FountaIN BuILdings $\quad$ I98

Notes 210

Short key bibliographies are given in the first note of each chapter or subdivision

SUPPLEMENTARY NOTES TO

SECOND EDITION

INDEX 


\section{LIST OF ILLUSTRATIONS}

FIGURES IN TEXT

FIG.

I Ancient Athens

PAGE

2 Thasos

3 Miletus

4 Olynthus

5 Olynthus, five blocks

6 Priene

7 Pergamon, upper city

8 Smyrna, restoration of archaic wall 28

9 Heraclea (Latmos), restoration of wall

Io Lato, agora

I I Athens, agora and surrounding district

I2 Athens, agora, pre-Persian buildings of west side 58

I3 Athens, agora, third century B.C. 60

I4 Corinth, agora district 63

Is Elis, excavations in and around agora $\quad 64$

I6 Miletus, north agora, end of fourth century B.C. $\quad 70$

I7 Miletus, agora, middle of second century B.C. $\quad 72$

I8 Priene, agora $\quad 74$

I9 Magnesia, agora $\quad 76$

20 Assos, agora 79

2I Pergamon, lower agora 80

22 Delos, central area 8I

23 Miletus, agora, second century A.D. $\quad 83$

24 Athens, agora, Hellenistic development of south side 85

25 Sanctuary of Aphaia, Aegina

26 Olympia, principal monuments in early fourth century B.C.

27 Olympia in time of Pausanias 


\section{HOW THE GREEKS BUILT CITIES}

FIG.

28 Shrine of Hera near Argos

29 Archaic stoa, Samos, restoration

30 Stoa of Philip, Megalopolis II4

3 I Stoa of Antigonus, Delos II4

32 Stoa of Attalus, Athens II6

33 Market-building, Aegae II6

34 Pnyx, Athens, sections I2I

35 Council-House, Olympia $\quad$ I26

36 Athens, Council-House and adjacent buildings $\quad$ I28

37 Council-House, Priene, restoration I3 I

38 Council-House, Miletus 132

39 Council-House, Notium I33

40 Prytaneion, Olympia 136

4I Prytaneion, Eleusis 137

42 Gymnasium attached to shrine of Asclepius, Epidaurus

43 Stadium, Delphi $\quad$ I59

44 Theatre of Thoricus $\quad$ I69

45 Athens, theatre and adjacent monuments I7I

46 New Pleuron, theatre and wall 174

47 House at Olynthus $\quad$ I89

48 Fifth century houses west of Areopagus, Athens $\quad 196$

49 Fountain of Glauke, Corinth 202

50 Plans of typical fountain-houses 204

SI Fountain Klepsydra, Athens 206

52 Fountain-house at Sicyon, plan and restored elevation 207

\section{PLATES}

PLATE

I Rhodes air view

II (a) Priene, central part, model 26

(b) Sacred Stoa, Priene, restoration 26 


\section{PLATES}

PLATB

III (a) Panakton (Gyphtokastro), Attic border fort

FACING PAGB

(b) Messene, section of wall and Arcadian Gate

IV Athens, west side of agora, model

V Miletus, harbour and north agora, model

VI Olympia, model

VII (a) Delphi, sanctuary of Apollo, model

(b) Athens, Acropolis, model

VIII (a) Unfinished temple at Segesta

(b) Temple of Artemis at Ephesus

IX Stoa of Athenians, Delphi

$\mathrm{X}$ Megalopolis, theatre and thersilion

II I

XI View to east from Delphi, with gymnasium

XII (a) Priene, lower gymnasium, stadium and city-wall, restoration

(b) Stadium attached to shrine of Asclepius at Epidaurus

XIII (a) Athens, primitive theatre and temple of Dionysus, restoration

(b) Theatre attached to shrine of Asclepius at Epidaurus

XIV (a) Priene, street leading from agora, restoration

(b) House-model from Perachora

XV (a) 'Villa of Good Fortune', Olynthus, restoration

(b) Courtyard of house, Priene, restoration

XVI (a) South-west fountain-house, Athens, model

202

(b) Fountain-house at Ialysos, Rhodes 


\section{ABBREVIATIONS}

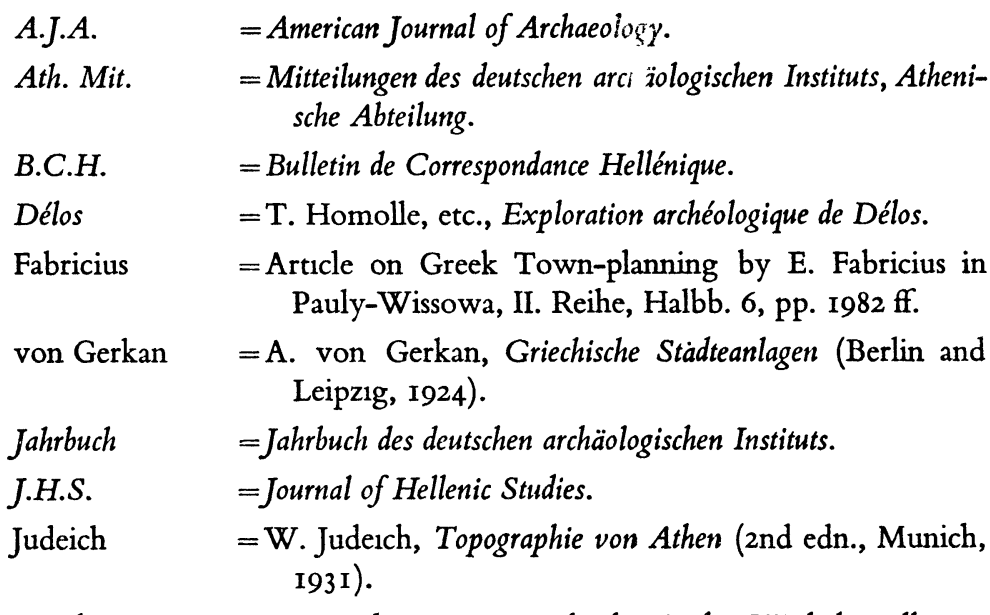

Krischen $\quad$ F. Krischen, Die griechische Stadt, Wiederherstellungen (Berlin, 1938).

McDonald =W. A. McDonald, The Political Meeting-places of the Greeks (Baltimore, 1943).

Milet $\quad=\mathrm{T}$. Wiegand, etc., Milet; Die Ergebnisse der Ausgrabungen und Untersuchungen.

Ö.J. = Jahreshefte des österreichischen archäologischen Instituts in Wien.

Olynthus =D. M. Robinson, etc., Excavations at Olynthus.

Pauly-Wissowa = Pauly-Wissowa, Real-Encyclopädie der classischen Altertumswissenschaft.

Travlos =J. Travlos, Poleodomike Exelixis ton Athenon (Athens, 1960).

Tritsch, Elis =F. Tritsch, 'Die Agora von Elis und die altgriechische Agora' (Ö.J., xxvii, pp. 64 ff.).

Weickert, Typen $=$ C. Weickert, Typen der archaischen Architektur in Griechenland und Kleinasien (Augsburg, 1929). 


\section{INTRODUCTORY}

s he neared the end of his Tour of Greece, which
he made in the second century A.D., Pausanias
came to a little place in Phocis called Panopeus. He hesitated to dignify it by the name of 'city' (polis) since it possessed 'no government offices or gymnasium, no theatre or agora or water flowing down to a fountain ' (x. 4. I), and consisted merely of a few miserable houses and one or two ancient shrines. Pausanias had visited innumerable cities, large and small, and no one knew better than he what was essential to a Greek city, what gave it its character. In addition he had a method of covering the ground at each important site, omitting nothing 'worth seeing', which makes it easy to see the elements of the city in their proper relation to one another, if one is not distracted by his long historical digressions. We can hardly do better than let him introduce us to our subject. Of course the date at which his descriptions were written is late from our point of view ; but that does not matter. Most of the old cities of European Greece had not changed radically in their general arrangement; and Pausanias had a strong antiquarian bias and wrote mainly of what were already ancient monuments in his day.

The visitor who takes Pausanias as his guide approaches by road from his last calling-place, noting interesting monuments by the wayside, including shrines and tombs. As he comes up to the city the dominant feature is the xix 
fortification wall, and he may pause to admire its construction. After he has entered one of the main gates the road leads quickly to the heart of the city, the agora. There he finds a large number of buildings, temples and simpler shrines, stoas or colonnades and various other public buildings, interspersed with numerous minor monuments, particularly sculpture. Incidentally, just as Greek sculpture must be placed in its architectural setting to be appreciated, so Greek architecture must be related to sculpture. Pausanias is very helpful in this matter; he mixes everything up together as he finds it; one sees the great buildings not standing isolated but embedded in monuments of the lesser arts; and nowhere more so than in the agora. There the monuments are grouped very loosely round a more or less open area of not very well-defined shape. The effect may be a little confusing or overpowering. In many ancient cities the acropolis rises above, and the visitor will naturally go there next, since some of the most venerable shrines are likely to be found there. The theatre may be built into a suitable part of the lower slopes. Interest will naturally be concentrated on the agora and the acropolis, but things which must not be missed will be found scattered over the rest of the city. The most systematic way of covering the ground is to follow the main streets leading out from the agora to the gates. What one will not do with Pausanias is to plunge into the mazes of back streets and dirty alleys where the ordinary houses of ordinary citizens are huddled together. Pausanias fails to satisfy our interest here; these are not what he calls 'worth seeing'. But fortunately we now know from archaeological evidence much more about Greek houses than we did a few years ago, 


\section{IN TRODUCTORY}

and we can imagine them filling in the framework which he provides. On the other hand, the abodes of the dead, at least the famous dead, appeal to him strongly, and the cemeteries are outside the city gates again, clustered thickly together or strung out along the roads. ${ }^{x}$ Other important elements, too, are found in the outskirts or suburbs ; those which need plenty of space, the stadium, for instance, and the gymnasia.

Not all Greek cities were precisely of this form. In particular one must remember that Pausanias confined his attention to old Greece on the European mainland; in some of the younger colonies new methods were evolved. But everywhere the Greek city consisted architecturally of certain elements essential to its rich and vigorous life. Some of these elements we shall examine in detail ; but first one must briefly consider the question how the city attained the form outlined above and other parallel or modified forms. 